\title{
Tingkat Laba dan Perubahan Laba: Manakah yang Lebih Relevan?
}

\section{Maria Prabani Putri Galuh Puspita}

Fakultas Ekonomika dan Bisnis Universitas Kristen Satya Wacana (UKSW) Salatiga Jl. Diponegoro No. 52-60 Salatiga 50711, Indonesia

\section{Info Article}

Keywords:

Earnings Levels; Earnings

Changes; and Stock Returns

ISSN (print) : 2598-7763

ISSN (online): 2598-7771

$\triangle$ Corresponding Author: Maria Prabani Putri G. Puspita: Tel. /Fax. 085293085852

E-mail:galuh96.prabani@gmail.com

\begin{abstract}
Abtract
This study aims to examine the relevance of information from earnings levels and earnings changes and compare the relevance of information between earnings levels and earnings changes. The population in this study are manufacturing companies listed on the Indonesia Stock Exchange (IDX) in 2014-2017. The sample selection uses a purposive sampling method. The sample used in this study amounted to 126 manufacturing companies listed on the Stock Exchange in 2014-2017. The analytical method used is simple linear regression. The results of the study show that earnings levels have a negative effect on stock returns, earnings changes have a positive effect on stock returns, earnings changes have an influence on stock returns that are stronger than earnings levels.
\end{abstract}

Citation: Maria Prabani Putri Galuh Puspita, (2019). Tingkat laba dan Perubahan Laba: Manakah yang Lebih Relevan? Accounting and Financial Review, 2 (2)

\section{PENDAHULUAN}

Perusahaan haruslah menyajikan informasi pada laporan keuangan yang menggambarkan kondisi sesungguhnya dari perusahaan, sehingga dapat memberikan manfaat bagi penggunanya. Informasi yang dapat memberikan manfaat bagi pengambilan keputusan pengguna haruslah informasi yang memiliki relevansi (Adhani \& Subroto, 2013). Relevansi informasi adalah sifat informasi yang berguna untuk memenuhi kebutuhan pengguna laporan keuangan dalam mengambil sebuah keputusan. Keputusan ekonomi pengguna informasi akan dipengaruhi oleh in- formasi yang relevan (Naimah, 2014). Informasi yang relevan dapat digunakan untuk menilai kejadian masa lalu, masa kini atau kejadian yang akan terjadi di masa mendatang, memastikan, atau memeriksa hasil penilaian mereka di masa lalu (Naimah, 2014). Konsep relevansi nilai informasi akuntansi dapat memberikan penjelasan bagaimana reaksi investor ketika suatu informasi akuntansi diumumkan, yang dapat dilihat dari adanya perubahan harga sekuritas. Reaksi tersebut menunjukkan bahwa isi dari informasi akuntansi adalah isu yang penting dalam pengambilan keputusan investasi (Puspitaningtyas, 2012). Hal ini karena kualitas informasi keuangan peru- 
sahaan yang tinggi berdampak pada efisiensi investasi ( $\mathrm{O}^{\prime}$ Connell, Abughazaleh, and Puurand, 2019).

Laba memiliki relevansi informasi yang berguna bagi investor dalam membuat suatu keputusan investasi. Laba adalah salah satu faktor utama investor dalam memberikan penilaian terhadap perusahaan dan memutuskan apakah investor akan melakukan investasi di perusahaan tersebut atau tidak (Permana, 2015; Prasetya dan Yulianto, 2019). Informasi laba akuntansi dapat dikatakan relevan apabila laba tersebut mampu menjelaskan perubahan harga saham atau return saham, sehingga laba akuntansi tersebut memiliki informasi yang bermanfaat untuk pengambilan keputusan investor (Haryanto, 2012).

Penelitian terdahulu mengenai tingkat laba dan perubahan laba telah dilakukan. Rizal \& Ana (2016) menyimpulkan bahwa tingkat laba berpengaruh positif terhadap return saham. Putra \& Widaningsih (2016) menyimpulkan bahwa tingkat laba memiliki pengaruh positif terhadap return saham. Trisnawati (2009) memiliki hasil yang berbeda dengan penelitian sebelumnya yaitu tingkat laba tidak memiliki pengaruh terhadap return saham. Pahmi (2018) juga menyimpulkan bahwa tingkat laba tidak berpengaruh terhadap return saham.

Ball, et al. (1993) menyimpulkan bahwa perubahan laba memiliki determinan ekonomi sistematis terkait dengan return saham. Yocelyn \& Christiawan (2012) menyimpulkan bahwa perubahan laba berpengaruh signifikan terhadap return saham. Sopini (2016) menyimpulkan bahwa perubahan laba memiliki pengaruh positif terhadap return saham. Penelitian tersebut berbeda dengan Nurdiana (2018) yaitu perubahan laba tidak memiliki pengaruh terhadap return saham.

Penelitian yang membandingkan antara relevansi informasi tingkat laba dan perubahan laba masih tergolong sedikit. Cheng, et al. (2013) menunjukkan bahwa tingkat laba lebih baik daripada perubahan laba dalam menjelaskan variasi imbalan. Penelitian tersebut berbeda dengan Yang (2018) yaitu menunjukkan bahwa tingkat laba dan perubahan laba bersama-sama memberikan nilai informasi relevan yang lebih tinggi daripada setiap variabel laba saja dalam menjelaskan return saham.

Tujuan penelitian ini adalah: 1) untuk menganalisis pengaruh tingkat laba terhadap return saham, 2) untuk menganalisis pengaruh perubahan laba terhadap return saham, 3) untuk mengetahui manakah yang lebih relevan antara tingkat laba dan perubahan laba. Penelitian ini diharapkan dapat bermanfaat bagi pemakai informasi keuangan khususnya investor untuk dapat menggunakan informasi laba sebagai dasar dalam pengambilan keputusan investasi dengan lebih tepat.

\section{PENGEMBANGAN HIPOTESIS}

\section{Tingkat Laba terhadap Return Saham}

Tingkat laba adalah profit yang diterima perusahaan pada tahun tersebut. Investor berani untuk melakukan investasi pada suatu perusahaan apabila memiliki tingkat laba yang tinggi (Fidhayatin \& Dewi, 2012). Semakin tinggi tingkat laba, maka semakin baik tingkat produktivitas perusahaan dan investor akan mendapatkan return saham yang tinggi, sehingga dapat meningkatkan rasa percaya investor pada perusahaan tersebut (Agustina \& Silvia, 2012). Laba yang diterima perusahaan pada tahun tersebut digunakan sebagai dasar dalam mengevaluasi kinerja perusahaan. Evaluasi tersebut digunakan untuk memperkirakan laba yang akan diperoleh perusahaan di masa mendatang. Investor akan bereaksi ketika tingkat laba yang dilaporkan perusahaan berbeda dengan ekspektasi para investor. Penelitian sebelumnya Rizal \& Ana (2016); Putra \& Widaningsih (2016) menyatakan bahwa tingkat laba berpengaruh positif terhadap return saham.

$\mathrm{H}_{1}$ : Tingkat laba berpengaruh positif terhadap return saham

\section{Perubahan Laba terhadap Return Saham}

Perubahan laba adalah penurunan atau kenaikan laba perusahaan dibandingkan dengan periode sebelumnya. Perubahan laba pada perusahaan dapat digunakan investor sebagai dasar dalam menentukan apakah investor akan membeli, menjual, atau mempertahankan investasi mereka (Agustina \& Silvia, 2012). Perubahan laba memiliki hubungan yang erat dengan kinerja keuangan perusahaan (Ifada \& Puspitasari, 2016). Oleh karena itu, investor perlu mengetahui kinerja perusahaan untuk dapat mengetahui situasi perusahaan yang sebenarnya. Perubahan laba dapat memberikan gambaran kepada para investor dengan melihat apakah perusahaan berubah menjadi lebih baik, relatif sama, atau lebih memburuk. Gambaran perubahan kinerja perusahaan tersebut yang akan direspon oleh para investor. Penelitian sebelumnya Yocelyn \& Christiawan (2012); Sopini (2016) menyatakan bahwa perubahan laba memiliki pengaruh positif terhadap 
return saham.

$\mathrm{H}_{2}$ : Perubahan laba berpengaruh positif terhadap return saham

\section{Tingkat Laba vs Perubahan Laba}

Tingkat laba dan perubahan laba merupakan bagian dari laba. Laba sendiri merupakan informasi relevan yang berguna bagi investor dalam mengevaluasi kinerja perusahaan dan menentukan apakah akan berinvestasi di perusahaan tersebut atau tidak. Tingkat laba perusahaan mengandung informasi penting tentang return saham masa depan (Bali, et al. 2008). Cheng, et al. (2013) juga berpendapat bahwa tingkat laba memiliki kekuatan prediktif untuk laba masa depan dan return di masa mendatang. Yang (2018) dalam menjelaskan informasi tambahan, tingkat laba memiliki kekuatan penjelas yang lebih tinggi daripada perubahan laba.

Penelitian Cheng, et al. (2013) menemukan bahwa tingkat laba lebih baik daripada perubahan laba dalam menjelaskan variasi imbalan. Oleh karena itu, tingkat laba memiliki relevansi informasi yang dapat digunakan untuk memperkirakan laba yang diharapkan di masa mendatang.

$\mathrm{H}_{3}$ : Tingkat laba memiliki pengaruh terhadap return saham yang lebih kuat daripada perubahan laba

\section{DATA DAN METODE}

Jenis penelitian ini adalah kuantitatif yang meneliti relevansi informasi laba pada perusahaan manufaktur yang tercantum di Bursa Efek Indonesia (BEI) tahun 2014-2017. Jenis data yang digunakan dalam penelitian ini adalah data sekunder. Data yang digunakan adalah dividen, laba, dan harga saham tahunan. Dividen dan laba diperoleh dari laporan keuangan perusahaan yang diterbitkan oleh Bursa Efek Indonesia (BEI) tahun 2014-2017, dan harga saham tahunan diperoleh dari yahoo.finance tahun 2014-2017.

Populasi dalam penelitian ini adalah perusahaan manufaktur yang terdaftar dalam Bursa Efek Indonesia (BEI) tahun 2014-2017. Pemilihan sampel dalam penelitian menggunakan teknik purposive sampling. Jumlah perusahaan sampel sebanyak 126 dengan periode pengamatan 4 tahun, sehingga jumlah pasang data sebanyak 504 data.

Penelitian ini menggunakan beberapa variabel dalam analisisnya, yaitu return saham sebagai variabel dependen, kemudian tingkat laba dan perubahan laba sebagai variabel independen. indikator pengukuran dari masing-masing variabel:

Return saham

Harga saham yang digunakan untuk menghitung return saham adalah closing price pada tanggal pengumuman laporan keuangan. Pengukuran return saham menurut Purwanti, et al. (2015) adalah:

$$
R S=\frac{H S_{t}-H S_{t-1}}{H S_{t-1}}
$$

Dimana: $\mathrm{RS}=$ Return saham; $\mathrm{HS}_{\mathrm{t}}=$ Closing price pada periode $\mathrm{t} ; \mathrm{HS}_{\mathrm{t}-1}=$ Closing price pada periode sebelumnya.

\section{Tingkat laba}

Tingkat laba merupakan laba yang diperoleh perusahaan pada periode berjalan. Pengukuran tingkat laba menurut Yendrawati \& Pratiwi (2014) sebagai berikut:

$$
E P S=\frac{\text { Laba setelah pajak }}{\text { Jumlah lembar saham yang beredar }}
$$

\section{Perubahan laba}

Perubahan laba adalah perbandingan antara laba yang diperoleh pada periode berjalan dengan periode sebelumnya (Agustina \& Silvia, 2012). Pengukuran perubahan laba adalah sebagai berikut:

$$
\triangle E P S=\frac{E P S_{t}-E P S_{t-1}}{E P S_{t-1}}
$$

Dimana: $\triangle \mathrm{EPS}=$ Perubahan EPS; $\mathrm{EPS}_{\mathrm{t}}=\mathrm{EPS}$ periode $\mathrm{t}$; $\mathrm{EPS}_{\mathrm{t}-1}=\mathrm{EPS}$ periode $\mathrm{t}-1$.

\section{Teknik Analisis Data}

Metode analisis dalam penelitian ini adalah regresi linier sederhana. Rumus regresi linier sederhana yang digunakan adalah sebagai berikut:

$$
\begin{aligned}
& R S_{t}=\alpha+\beta \text { EPS }_{t}+\epsilon \\
& R_{t}=\alpha+\beta \Delta \text { PPS }_{t}+\epsilon
\end{aligned}
$$

Dimana: $\mathrm{RS}_{\mathrm{t}}=$ Return saham; $\alpha=$ Konstanta; $\beta=$ Koefisien regresi; EPS ${ }_{\mathrm{t}}$ : Tingkat laba; $\triangle \mathrm{EPS}_{\mathrm{t}}=\mathrm{Pe}-$ rubahan laba dan $\varepsilon=$ Error

Pengujian dengan metode regresi linier sederhana digunakan untuk mengetahui apakah tingkat laba berpengaruh positif terhadap return saham dan apakah perubahan laba berpengaruh positif terhadap return saham.

\section{HASIL}

\section{Deskripsi Data}

Karakteristik variabel-variabel dideskripsikan melalui statistik deskriptif dengan melihat nilai dari minimal, maksimal, rata-rata, dan 
standar deviasi.

Tabel 1. Statistik Deskriptif RS, EPS, $\triangle$ EPS

\begin{tabular}{lrrrr}
\hline Variabel & Minimal & Maksimal & $\begin{array}{l}\text { Rata- } \\
\text { rata }\end{array}$ & $\begin{array}{l}\text { Std. } \\
\text { Deviasi }\end{array}$ \\
\hline RS & $-0,88$ & 13,59 & 0,23 & 1,12 \\
EPS & $-3013,52$ & 9034,24 & 176,89 & 769,27 \\
$\Delta$ EPS & $-64,79$ & 576,55 & 0,68 & 26,58 \\
\hline
\end{tabular}

Sumber: Data Olahan, 2019

Return saham selama tahun 2014-2017 menunjukkan nilai yang positif, yaitu sebesar 0,23 . Hal ini mengindikasikan harga saham pada perusahaan manufaktur cenderung meningkat. Meskipun ada beberapa saham yang mengalami penurunan harga saham, hal ini tercermin dari nilai minimm return saham sebesar $-0,88$.

Rata-rata laba perusahaan, yang dilihat dari nilai EPS sebesar 176,89. Hal ini menunjukkan bahwa secara umum perusahaan yang bergerak di manufaktur cenderung memiliki kinerja yang baik. Nilai rata-rata lebih kecil daripada standar deviasi menunjukkan adanya keberagaman tingkat laba yang dihasilkan perusahaan selama periode pengamatan

Perubahan laba ( $\triangle E P S)$ selama tahun 20142017 memiliki nilai minimal sebesar $-64,79$ dan nilai maksimal sebesar 576,55. Nilai rata-rata perubahan laba $68 \%$, artinya perbandingan laba yang diperoleh dari periode berjalan dengan periode sebelumnya seluruh perusahaan sebesar $68 \%$. Nilai rata-rata lebih kecil daripada standar deviasi menunjukkan adanya keberagaman perubahan laba yang dialami perusahaan selama periode pengamatan.

Pengujian normalitas data dilakukan dengan uji Normalitas Kolmogorov-Smirnov. Berdasarkan hasil pengujian normalitas data menunjukkan data berdisitribusi normal.

Berdasarkan uji asumsi klasik, data telah memenuhi asumsi klasik. Berdasarkan hasil pengujian heretoskedastisitas menunjukkan tidak ada gejala heteroskedastisitas. Uji heteroskedasiras model regresi terjadi ketidaksamaan variance antara satu pengamatan dengan pengamatan lainnya. Untuk uji autokorelasi, menunjukkan tidak terjadi autokorelasi. Hal ini ditunjukkan dengan nilai DW sebesar 2,100, yang berada pada kisaran nilai 1,85716 (du) - 2,14284 (4-du).

\section{Hasil Pengujian Hipotesis}

Pengujian hipotesis dilakukan dengan metode regresi linier berganda. Tujuan dari pengujian ini adalah untuk mengetahui apakah tingkat laba memiliki relevansi informasi, apakah perubahan laba memiliki relevansi informasi, dan manakah yang lebih relevan antara tingkat laba dan perubahan laba. Hasil analisis regresi disajikan pada Tabel 2.

Tabel 2. Hasil Analisis Regresi

\begin{tabular}{lllll}
\hline Model & $\begin{array}{l}\text { Standardized } \\
\text { Coefficients } \\
\text { Beta }\end{array}$ & $\mathrm{T}$ & Sig. & $\begin{array}{l}\text { Adjusted R } \\
\text { Square }\end{array}$ \\
\hline EPS & $-0,149$ & $-2,112$ & 0,036 & 0,017 \\
$\Delta$ EPS & 0,360 & 4,519 & 0,000 & 0,123 \\
\hline
\end{tabular}

Berdasarkan hasil analisisi regresi (Tabel 2) memperlihatkan bahwa variabel tingkat laba (EPS) memiliki koefisien negatif sebesar -0,123 dan $p$-value (sig). sebesar 0,036. Hal ini bermakna apabila tingkat laba mengalami peningkatan maka return saham yang akan diterima mengalami penurunan, begitu sebaliknya. Koefisien determinasi $\left(\mathrm{R}^{2}\right)$ tingkat laba sebesar $1,7 \%$, artinya $1,7 \%$ perubahan return saham dijelaskan oleh tingkat laba (EPS), sedangkan sisanya sebesar 98,3\% dijelaskan oleh variabel lain.

Variabel perubahan laba ( $\triangle E P S)$ memiliki koefisien positif sebesar 0,281 dan p-value (sig). 0,000 . Hasil tersebut bermakna apabila perubahan laba mengalami peningkatan maka return saham yang diterima mengalami peningkatan, begitu sebaliknya. Koefisien determinasi $\left(\mathrm{R}^{2}\right)$ perubahan laba sebesar $12,3 \%$, bermakna perubahan return saham sebesar 12,3\% dijelaskan oleh perubahan laba $(\triangle \mathrm{EPS})$, sedangkan sisanya sebesar $87,7 \%$ dijelaskan oleh variabel lain.

\section{PEMBAHASAN}

\section{Tingkat Laba dan Return Saham}

Hasil penelitian menunjukkan bahwa tingkat laba berpengaruh signifikan dengan arah negatif terhadap return saham. Temuan ini tidak sejalan dengan penelitian dari Rizal \& Ana (2016); Putra \& Widaningsih (2016), Ananda (2018), Haryanto, dkk. (2018) yang menyimpulkan tingkat laba berpengaruh positif terhadap return saham.

Laba yang diumumkan perusahaan pada tanggal pengumuman laporan keuangan tidak mendapat respon positif dari investor. Terdapat pengaruh negatif tingkat laba terhadap return, hal ini mengindikasikan adanya respon negatif dari investor ketika tingkat laba diumumkan yang berarti ketika tingkat laba yang diumumkan tinggi belum tentu return saham yang akan didapat juga tinggi dan begitu sebaliknya. Hal ini mungkin disebabkan oleh persistensi laba rendah yang dimiliki perusahaan. Persistensi laba adalah sifat laba yang dapat dimanfaatkan sebagai dasar un- 
tuk laba periode mendatang (Andari, 2017). Laba terdiri dari komponen permanen dan transitory. Perusahaan yang memiliki persistensi laba rendah berarti memiliki komponen transitory yang lebih tinggi yang artinya bahwa laba tidak dapat dijadikan dasar estimasi untuk laba dimasa mendatang. Hal tersebut menyebabkan adanya respon negatif dari investor ketika laba diumumkan. Penelitian ini sejalan dengan penelitian Fitri, et al. (2017) yang memberikan hasil bahwa tingkat laba berpengaruh negatif terhadap return saham. Namun peneltian ini sejalan dengan penelitian Dutt, \& Jenner (2013) dimana laba berpengaruh terhadap return saham.

\section{Perubahan Laba dan Return saham}

Berdasarkan hasil analisis menunjukkan bahwa perubahan laba berpengaruh signifikan dengan arah positif dengan return saham. Hal ini menunjukkan investor merespon positif perubahan laba terhadap return saham.

Perubahan laba dapat memberikan gambaran kinerja perusahaan dengan melihat apakah kinerja perusahaan mengalami penurunan atau kenaikan, sehingga ketika kinerja perusahaan mengalami peningkatan maka return saham yang akan diterima investor tinggi dan begitu sebaliknya. Gambaran kinerja tersebut yang akan direspon positif oleh investor untuk melakukan investasi di perusahaan tersebut atau tidak dan nantinya akan mempengaruhi pergerakan harga saham atau return saham. Hasil temuan ini sejalan dengan penelitian yang dilakukan oleh Purwanti, dkk. (2015); Yocelyn \& Christiawan (2012); Sopini (2016).

\section{Tingkat Laba vs Perubahan Laba}

Hasil penelitian menunjukkan bahwa tingkat laba tidak memiliki pengaruh terhadap return saham yang lebih kuat daripada perubahan laba. Hal ini menunjukkan bahwa perubahan laba memiliki informasi yang lebih relevan daripada tingkat laba. Hasil temuan ini berbeda dengan hasil penelitian yang telah dilakukan oleh Cheng, et al. (2013) yang menyatakan tingkat laba lebih baik daripada perubahan laba dalam menjelaskan return saham.

Para investor cenderung menggunakan perubahan laba untuk mengevaluasi kinerja perusahaan bukan hanya dengan menggunakan tingkat laba yang diperoleh perusahaan pada periode berjalan. Hal ini dikarenakan perubahan laba dapat menunjukkan tingkat pertumbuhan perusahaan dari tahun ke tahun, apakah profitabilitas perusahaan mengalami kenaikan atau penurunan. Penelitian ini sejalan dengan Winelfia (2018) menyatakan bahwa perubahan laba memperkuat hubungan laba dengan return saham. Salah satu faktor tingkat laba memiliki relevansi informasi yang lebih rendah adalah adanya transitory income yang menyebabkan tingkat laba tidak dapat digunakan untuk memprediksi laba dimasa depan.

\section{SIMPULAN DAN SARAN}

Hasil analisis dan pembahasan dapat disimpulkan bahwa 1) Tingkat laba berpengaruh negatif terhadap return saham; 2) Perubahan laba berpengaruh positif terhadap return saham; 3) Perubahan laba memiliki pengaruh terhadap return saham yang lebih kuat daripada tingkat laba.

Penelitian ini dilakukan pada perusahaan manufaktur tanpa melakukan pengelompokkan keaktifan di pasar saham. Selain sebagai variabel prediktor hanya digunakan laba dan perubahan laba. Untuk penelitian yang akan datang dapat dilakukan dengan melakukan pengelompokkan perusahaan-perusahaan dengan tingkat keaktifan perdagangannya di pasar saham. Selain itu variable penelitian dapat memasukkan risiko sistematis karaktristik perusahaan.

\section{DAFTAR PUSTAKA}

Adhani, Y. S., \& Subroto, B. (2013). Relevansi Nilai Informasi Akuntansi. Jurnal Ilmiah Mahasiswa FEB Universitas Brawijaya, 2 (2).

Agustina, \& Silvia. (2012). Pengaruh Rasio Keuangan Terhadap Perubahan Laba pada Perusahaan Manufaktur yang Terdaftar di Bursa Efek Indonesia. Jurnal Wira Ekonomi Mikroskil, 2 (2): 113-122.

Ananda,F. A., (2018). Struktur Modal, Kinerja Perusahaan dan Altman Z-Score Pengaruhnya Terhadap Ekspektasi Investor. Accounting and Financial Review, 1 (1): 916.

Andari, A. T. (2017). Analisis Perbedaan Kualitas Akrual dan Persistensi Laba Sebelum dan Sesudah Konvergensi IFRS. Jurnal Kajian Akuntansi, 1 (2): 133-147.

Bali, T. G., Demirtas, K. O., \& Tehranian, H. (2008). Aggregate Earnings, Firm-Level Earnings, and Expected Stock Returns. The Journal of Financial and Quantitative Analysis, 43(3): 657-684.

Ball, R., Kothari, S. P., \& Watts, R. L. (1993). Economic Determinants of the Relation 
between Earnings Changes and Stock Returns. The Accounting Review, 68(3): 622638.

Cheng, C. S., Lee, B.-S., \& Yang, S. (2013). The Value Relevance of Earnings Levels in The Return-Earnings Relation. International Journal of Accounting and Information, 21 (4): 260-284.

Dutt, T. And Jenner, Humphery Mark. (2013). Stock return volatility, operating performance and stock returns: International evidence on drivers of the 'low volatility' anomaly. Journal of Banking \& Finance. 37 (3): 999-1017

Fidhayatin, S. K., \& Dewi, N. H. (2012). Analisis Nilai Perusahaan, Kinerja Perusahaan dan Kesempatan Bertumbuh Perusahaan Terhadap Return Saham pada Perusahaan Manufaktur yang Listing di BEI. The Indonesian Accounting Review, 2 (2): 203-214.

Fitri, L. N., Supriyanto, A., \& Andini, R. (2017). Pengaruh Laba Akuntansi, Current Ratio, Return on Asset, Debt to Equity Ratio, dan Ukuran Perusahaan terhadap Return Saham. Jurnal Ilmiah Mahasiswa S1 Akuntansi Universitas Pandanaran, 3 (3).

Haryanto, C. M. (2012). Pengaruh Relevansi Laba Akuntansi Terhadap Return Saham dengan Risiko Perusahaan dan Leverage sebagai Variabel Pemoderasi pada Perusahaan Manufaktur di BEI. Jurnal Ilmiah Mahasiswa Akuntansi, 1 (1): 9-15.

Haryanto, S., Rahadian, N., Mbapa, M.F.I., Rahayu, E.N. dan Febriyanto, K.V. (2018). Kebijakan Hutang, Ukuran Perusahaan dan Kinerja Keuangan Terhadap Nilai Perusahaan: Industri Perbankan di Indonesia. Accounting and Financial Review, 1 (2): 62-70.

Ifada, L. M., \& Puspitasari, T. (2016). Analisis Pengaruh Rasio Keuangan Terhadap Perubahan laba. Jurnal Akuntansi $\mathcal{E}$ Auditing, 13 (1): 97-108.

Naimah, Z. (2014). Relevansi Nilai Informasi Akuntansi: Suatu Kajian Teoritis. Jurnal Buletin Studi Ekonomi, 19 (1): 105-117.

Nurdiana, D. (2018). Pengaruh Informasi Laba, Arus Kas dan Size Perusahaan Terhadap Return Saham pada Perusahaan Food and Beverages yang Terdaftar di Bursa Efek Indonesia. Jurnal Elektronik REKAMAN, 2 (1): 111-126.

O'Connell, V., Abughazaleh, N., and Puurand, E., (2019). The Influence of Accounting Information on Invesment Efficiency:
Evidence from European Stock Markets. ASBBS Proceedings; San Diego 26: 386405. San Diego: American Society of Business and Behavioral Sciences.

Pahmi, S. (2018). Pengaruh Laba, Arus Kas, dan Komponen Arus Kas, Terhadap Return Saham (Studi pada Perusahaan Manufaktur yang Terdaftar di BEI. Media Bina Ilmiah, 12(9): 409-420.

Permana, A. B. (2015). Pengaruh Relevansi Nilai Terhadap Keputusan Investor. Jurnal Akuntansi Unesa, 3 (2).

Prasetya, A.R., and Yulianto, A. (2019). Determinants of Investment Decisions with Growth Opportunities as Moderating Varia-ble. Accounting Analysis Journal 8 (1): $17-23$

Purwanti, S., Masitoh, E., \& Chomsatu, Y. (2015). Pengaruh Laba Akuntansi dan Arus Kas Terhadap Return Saham Perusahaan yang Listing di BEI. Jurnal Akuntansi dan Pajak, 16 (1): 113-123.

Puspitaningtyas, Z. (2012). Relevansi Nilai Informasi Akuntansi dan Manfaatnya Bagi Investor. Jurnal Ekonomi dan Keuangan, 16 (2): 164-183.

Putra, Y. R., \& Widaningsih, M. (2016). Pengaruh Laba Akuntansi, Komponen Arus Kas, dan Dividend Yield Terhadap Return Saham (Studi pada Perusahaan Sektor Pertambangan di Bursa Efek Indonesia Periode 2012-2014. Jurnal Riset Akuntansi \& Keuangan, 4 (2): 1047-1058.

Rizal, N., \& Ana, S. R. (2016). Pengaruh Laba Akuntansi dan Arus Kas serta Ukuran Perusahaan Terhadap Return Saham (Studi Empiris pada Perubahan Perbankan yang Terdaftar di BEI Tahun 2012-2014). Jurnal Ilmiah Bisnis dan Keuangan, 6 (2): 65-76.

Sopini, P. (2016). Pengaruh Laba Akuntansi dan Arus Kas Terhadap Return Saham. Eksis, 7 (1): 69-79.

Trisnawati, I. (2009). Pengaruh Economic Value Added, Arus Kas Operasi, Residual Income, Earnings, Operating Leverage dan Market Value Added Terhadap Return Saham. Jurnal Bisnis dan Akuntansi, 11 (1): 65-78.

Winelfia, D. (2018). Relevansi Nilai Laba Operasi, Laba Bersih, dan Laba Komprehensif . Jurnal Akuntansi, 6 (2).

Yang, S. (2018). A Reexamination of Earnings Persistence on The Incremental Value Relevance of Earnings Levels and Earnings 
Changes. International Journal of Accounting and Financial Reporting, 8 (2): 126-151.

Yendrawati, R., \& Pratiwi, R. S. (2014). Relevansi Nilai Informasi Laba dan Arus Kas Terhadap Harga Saham. Jurnal Dinamika Manajemen, 5 (2): 161-170.

Yocelyn, A., \& Christiawan, Y. J. (2012). Analisis Pengaruh Perubahan Arus Kas dan Laba Akuntansi Terhadap Return Saham pada Perusahaan Berkapitalisasi Besar. Jurnal Akuntansi dan Keuangan, 14 (2): 81-90. 